\title{
Analysis of Mechanical Properties of AISi9Mg Alloy with Al, Ti and B Additions
}

Tomasz Lipiński

University of Warmia and Mazury in Olsztyn, The Faculty of Technical Sciences, St: Oczapowskiego 11, 10-957 Olsztyn, Poland, email: tomaszlipinski.tl@gmail.com

The initial structure of AISi9Mg alloy is composed of granular and acicular $\beta$ phase, with $\alpha$ phase as matrix. The hard, irregular, often pointed $\beta$ phase is responsible for the poor mechanical properties of said alloy. This composition is responsible for the alloy's low strength parameters, and it limits the extent of practical applications. This study presents the results of modification of an AISi9Mg alloy with aluminum, boron and titanium in different ranges produced as a melted modifier. The influence of the analyzed modifiers on the microstructure and mechanical properties of the silumin was presented in graphs. Thermal analysis has been used to characterize the thermal effects processes of AISi9Mg alloy. The modification of a hypoeutectic AlSi9Mg alloy improved the alloy's properties. The results of the tests indicate that the mechanical properties of the modified alloy are determined by the sequence in which the components are introduced to the alloy.

Keywords: Al-Si alloy, Silumin, Modification, Mechanical properties

\section{References}

[1] MICHNA, S., LUKAC, I., OCENASEK, V., KORENY, R., DRAPALA, J., SCHNEIDER, H., MISKUFOVA, A. (2005). Encyclopaedia of aluminium, Adin s.r.o. Presov (in Czech).

[2] MONDELFO, L.F. (1978). Aluminium alloys: Structure and Properties, London, Butterworth.

[3] SVOBODOVÁ, J., CAIS, J., MICHNA, S., BRU゚HA, M. (2013). Research of Corrosion Properties of Al-Si Alloys Antimony Alloyed. In: Manufacturing Technology, Vol. 13, No. 3, pp. 404-409.

[4] MICHNA, S., CAIS, J., MICHNOVA, L. (2015). Research of the Cause Cracking Hot-Rolled Block Made of AlMg5 Alloys. In: Manufacturing Technology, Vol. 15, No. 4, pp. 614-620.

[5] HONZÁTKO, R., MICHNA, S., CAIS, J. (2013). The Influence of Porosity on Mechanical Properties of Casts Produced from Al - Si Alloys. In: Manufacturing Technology, Vol. 13, No. 3, pp. 319-324.

[6] MICHNA, S., NÁPRSTKOVÁ, N. (2012). The use of fractography in the analysis of cracking after formed workpiece blank mechanical machining from the AlCuSnBi alloy. In: Manufacturing Technology, Vol. 12, No. 13, pp. 174-178.

[7] NOVÁ, I., MACHUTA, J. (2013). Squeeze casting results of aluminium alloys. In: Manufacturing Technology, Vol. 13, No. 1, pp. 73-79.

[8] BRUNA, M., SLÁDEK, A. (2016). Hot Tearing Evaluation of Al - Based Alloys. In: Manufacturing Technology, Vol. 16, No. 2, pp. 323 - 327.

[9] MACHUTA, J., NOVÁ, I. (2016). Analysis of Heat Transfer Conditions in the Sand and Metal Moulds and Their Effect on the Solidification of the Casting. In: Manufacturing Technology, Vol. 16, No. 2, pp. $380-384$.

[10] RICHTÁRECH, L., BOLIBRUCHOVÁ, D., KUCHARCÍKOVÁ, E. (2016). Appliciation of Heat Treatment for Elimination of Iron in Secondary Al-Si Alloy. In: Manufacturing Technology, Vol. 16, No. 2, pp. 431 - 436.

[11] GRZINČIČ, M., LUKAC, I. (2013).Optimization of the Solution Annealing Treatment of the AlSi10Mg(Cu) Alloy. In: Manufacturing Technology, Vol. 13, No. 4, pp. 455-458.

[12] KOVALČ́́K, T., STOULIL, J., SLÁMA, P., VOJTĚCH, D. (2015). The Influence of Heat Treatment on Mechanical and Corrosion Properties of Wrought Aluminium Alloys 2024 and 6064. In: Manufacturing Technology, Vol. 15, No. 4, pp. 54-61.

[13] TILlOVÁ, E., CHALUPOVÁ, M., HURTALOVÁ, L., BELAN, J. (2015). Impact Properties of Self-Hardening Aluminium Alloy (Alzn10si8mg) at Elevated Temperatures. In: Manufacturing Technology, Vol. 15, No. 4, pp. 720-727.

[14] WOŁCZYŃSKI, W., GUZIK, E., WAJDA, W., JĘDRZEJCZYK, D., KANIA, B., KOSTRZEWA, M. (2012). CET in Solidifying Roll - Thermal Gradient Field Analysis. In: Archives of Metallurgy and Materials No. 57, pp. 105-117.

[15] NÁPRSTKOVÁ, N., SVOBODOVÁ, J., CAIS, J. (2013). Influence of strontium in AlSi7Mg0.3 alloy on the tool wear. In: Manufacturing Technology, Vol. 13, No. 3, pp. 368 - 373. 
[16] ZIHALOVA, M., BOLIBRUCHOVA, D., (2016). Evaluation of Vanadium Influence in AlSi10MgMn Alloy with Increased Iron Level. In: Manufacturing Technology, Vol. 16, No. 2, pp. $471-475$.

[17] NOVÁ I., MACHUTA J. (2014). Monitoring of the Structure and Quality of Aluminium Castings in Moulds of Gypsum Mixtures. Manufacturing Technology Vol. 14, No. 3, pp. 381 - 387.

[18] NÁPRSTKOVÁ N., KUŚMIERCZAK S., CAIS J. (2013). Modification of AlSi7Mg0.3 alloy by strontium. Manufacturing Technology Vol. 13, No. 3, pp. $373-380$.

[19] MICHNA Š., NÁPRSTKOVÁ N. (2012). The use of fractography in the analysis of cracking after formed workpiece blank mechanical machining from the AlCuSnBi alloy, Manufacturing Technology Vol. 12/13, pp. 174-178,

[20] RICHTÁRECH, L., BOLIBRUCHOVÁ, D. (2014). Effect of Selected Elements on the Microstructure of Secondary Al-Si Alloys. In: Manufacturing Technology, Vol. 14, No. 3, pp. 431 - 437.

[21] ZIHALOVA, M., BOLIBRUCHOVA, D. (2014). Vanadium and Chromium Impact to Microstructure of AlSi10MgMn Alloy with Elevated Iron Content. In: Manufacturing Technology, Vol. 14, No. 3, pp. 498 - 502.

[22] LIPIŃSKI, T., SZABRACKI, P. (2015). Mechanical Properties of AlSi9Mg Alloy with a Sodium Modifier. In: Solid State Phenomena Vol. 223, pp 78-86. TTP Switzerland.

[23] HRICOVA J., NAPRSTKOVA N. (2015). Surface Roughness Optimization in Milling Aluminium Alloy by Using the Taguchi's Design of Experiment. Manufacturing Technology Vol. 15, No. 4, pp. 541-546.

[24] LIPIŃSKI T. (2015). Influence of Surface Refinement on Microstructure of Al-Si Cast Alloys Processed by Welding Method. Manufacturing Technology Vol. 15, No. 4, pp. 576-581.

[25] LIPIŃSKI T. (2015). Modification of Al-11\% Si Alloy with Cl - Based Modifier. Manufacturing Technology Vol. 15, No. 4, pp. 581-587.

[26] SKOČILASOVÁ, B., SKOČILAS, J. (2015). Solidification of the Aluminium Alloy in the Mold. In: Manufacturing Technology, Vol. 15, No. 5, pp. 909-914.

[27] NÁPRSTKOVÁ, N., CAIS, J., SVOBODOVÁ, J. (2013). The Effect of Modification by Strontium of the AlSi7Mg0.3 Alloy on the Surface Roughness. In: Manufacturing Technology, Vol. 13, No. 3, pp. 380 - 384.

[28] JACKSON, K.A., HUNT, J.D. (1966). Lamellar and rod eutectic growth. Trans. Metall. Soc. AIME: 1129-1142.

[29] MONDELFO, L.F. (1976.) Aluminium alloys. Structure and properties. Butter Wooths. London Boston.

[30] WOŁCZYŃSKI W, GUZIK E, WAJDA W, JĘDRZEJCZYK D, KANIA B, KOSTRZEWA M. (2012). CET in Solidifying Roll - Thermal Gradient Field Analysis, Archives of Metallurgy and Materials Vol. 57, No. 1, pp. 105117.

[31] KUCHARSKA B, WRÓBEL A, KULEJ E, NITKIEWICZ Z. (2010). The X-Ray Measurement of the Thermal Expansibility of Al-Si Alloy in the Form of a Cast and a Protective Coating on Steel", Solid State Phenomena 163, pp. 286-290.

[32] FERDIAN D., SUHARNO B., DUPLOYER B., TENAILLEAU C., SALVO L., LACAZE J. (2012). Differential Thermal Analysis Assessment of Beta Phase Precipitation in Al-6.5Si-1Fe Alloy. Trans Indian Inst Met Vol. 65, No. 6, pp. 821-825.

[33] PRŮŠA, F., VOJTĚCH, D., BERNATIKOVÁ, A., DVORSKÝ, D. (2015). Mechanical Alloying: A Way How to Improve Properties of Aluminium Alloys. In: Manufacturing Technology, Vol. 15, No. 6, pp. 1036-1043.

[34] NOVÁ, I., MACHUTA, J. (2016). Simulation Calculations of Solidification and Cooling of Copper Alloy Casts. In: Manufacturing Technology, Vol. 15, No. 4, pp. 591-596.

[35] BOLIBRUCHOVÁ, D., RICHTÁRECH, L. (2016). Possibilities of Using Al-Si-Mg Alloys with Higher Fe Content for Demanding Castings In: Manufacturing Technology, Vol. 16, No. 2, pp. 317 - 323.

[36] GRZINČIČ, M., LUKAC, I. (2014). Identification of Intermetallic Phases in the Alloy AlSi6Cu4. In: Manufacturing Technology, Vol. 14, No. 2, pp. 160-166.

[37] WEISS, V., SVOBODOVÁ, J. (2015). The Use of Colour Metallography and EDS for Identification of Chemical Heterogeneity of Selected Aluminium Alloys Copper and Zinc Alloyed. In: Manufacturing Technology, Vol. 15, No. 6, pp. 1048-1053. 